\title{
Soil Disinfestation Efficacy against Soil Fungal Pathogens in Strawberry Crops in Spain: An Overview
}

\author{
Berta de los Santos ${ }^{1, *}$, Juan Jesús Medina ${ }^{2}$, Luis Miranda ${ }^{1}$, José Antonio Gómez ${ }^{1}$ and Miguel Talavera ${ }^{3}$ (D) \\ 1 IFAPA Las Torres, Ctra. Sevilla-Cazalla, Km. 12.2, 41200 Alcalá del Río, Sevilla, Spain; \\ luis.miranda.enamorado@juntadeandalucia.es (L.M.); josea.gomez@juntadeandalucia.es (J.A.G.) \\ 2 IFAPA Huelva, Julio Caro Baroja s/n, 21002 Huelva, Sevilla, Spain; juanj.medina@juntadeandalucia.es \\ 3 IFAPA Alameda del Obispo, Av. Menéndez Pidal s/n, 14004 Córdoba, Sevilla, Spain; \\ miguelf.talavera@juntadeandalucia.es \\ * Correspondence: berta.santos@juntadeandalucia.es; Tel.: +34-671-532-8666
}

check for updates

Citation: de los Santos, B.;

Medina, J.J.; Miranda, L.; Gómez, J.A.;

Talavera, M. Soil Disinfestation

Efficacy against Soil Fungal

Pathogens in Strawberry Crops in Spain: An Overview. Agronomy 2021, 11, 526. https://doi.org/10.3390/ agronomy11030526

Academic Editor: Gianluca Baruzzi and Giancarlo Roccuzzo

Received: 30 January 2021

Accepted: 9 March 2021

Published: 11 March 2021

Publisher's Note: MDPI stays neutral with regard to jurisdictional claims in published maps and institutional affiliations.

Copyright: (c) 2021 by the authors. Licensee MDPI, Basel, Switzerland. This article is an open access article distributed under the terms and conditions of the Creative Commons Attribution (CC BY) license (https:// creativecommons.org/licenses/by/ $4.0 /)$.

\begin{abstract}
Background: Strawberry cultivation is highly dependent on soil disinfestation for proper development. Since the definitive methyl bromide phase-out, other chemicals have been used as alternatives. This research provides an overview on the efficacies of soil disinfestation methods on controlling soil fungal diseases of strawberry. (2) Methods: The efficacy of several soil disinfestation methods on soil fungal pathogens (SFP: Fusarium spp. and Macrophomina phaseolina) was analyzed in experimental field trials during eleven growing seasons. (3) Results: Average efficiencies in reducing soil pathogen inocula for soil disinfestation techniques are given. Soil disinfestations with chloropicrin, allyl isothiocyanate, dazomet, 1,3-dichloropropene:chloropicrin, methyl iodide:chloropicrin, and dimethyl disulfide reduced Fusarium spp. and M. phaseolina soil inocula by more than $90 \%$. Combination of solarization with organic manures (biosolarization) reduced Fusarium spp. soil populations by $80 \%$ and M. phaseolina by $79 \%$. Reductions in plant mortality and increases in fruit yields over the untreated controls did not differ between chemically fumigated and biosolarized plots. (4) Conclusions: Soil fungal pathogens are effectively controlled by chemical fumigation of soils in intensive strawberry crops in Spain. In the case of mixed infestations of SFP with nematodes, the most efficient treatment in suppressing soil-borne diseases was soil fumigation with 1,3-dichloropropene:chloropicrin, but other alternative chemicals, such as allyl isothiocyanate, dazomet, and dimethyl disulfide, provided high efficacies in reducing the SFP inocula. Soil biosolarization is proposed as an effective alternative to chemical soil fumigation for strawberry cultivation in Southern Spain when SFP inocula is not remarkably high.
\end{abstract}

Keywords: soil fungal pathogens; soil biosolarization; soil disinfestation; strawberry

\section{Introduction}

The strawberry (Fragaria $\times$ ananassa Duch.) is an important crop worldwide, which is mainly produced in China, USA, Mexico, Egypt, Turkey, and Spain [1]. Strawberry-growing in Spain is concentrated in the southwestern region (Huelva province), which constitutes up to $93 \%$ of total Spanish production, with 6867 ha yielding 377,596 tons with a market value of 392 million $€$ in 2016 [2]. Huelva is a European leader in strawberry production (25-33\% of the total European production) and the world's largest exporter. Fruits for fresh consumption are mainly exported to Northern European countries. Strawberry production in Huelva started in the late 1960s and increased until 2015 when it levelled off at about 350,000 tons per year. Strawberry crops in Spain are intensive monoculture systems in which fruits are grown under temporary plastic high tunnels in annual cropping cycles from October to May. Most strawberry transplants cultivated in Huelva are produced in open-field nurseries in central northern Spain and shipped to the fruit-production fields. The harvest period is from January to late May, and during the summer months, July to 
September, the fields are left fallow. Crop rotation with other crops is not feasible, mainly due to the long strawberry cropping cycles and economic profitability.

As a result of monoculture and polyphagia of many soil-borne pathogens, fungi such as Macrophomina phaseolina and Fusarium spp. [3-6] and nematodes such as Meloidogyne hapla, Pratylenchus penetrans, and Hemicycliophora spp. [7] are widely extended in the province of Huelva, with prevalences of about $60-80 \%$ of infested plots, and constitute a key limiting factor to achieving strawberry premium quality and economically sustainable yields. Despite an extended use of chemical soil fumigation, it has been estimated that current yield losses in the area caused by soil fungal pathogens (SFPs) are around 10\% [8]. There are no strawberry-resistant cultivars against these pathogens, and therefore their control has relied upon reducing pathogen inocula by soil disinfestation with fumigant agrochemicals (1,3-dichloropropene, chloropicrin, or metam sodium) applied by injection or emulsified in irrigation water. To increase its effectiveness, the soil is covered for several weeks with polyethylene plastic sheets, which maintains the concentration of fumigants in the soil for a longer duration and reduces gas emissions into the atmosphere. Soil chemical disinfestation is practiced in $83 \%$ of strawberry plots in Spain [9].

However, the continuous use of chemical soil fumigants causes environmental problems due to residue accumulation with a high risk of groundwater contamination, and undesirable effects on soil biodiversity. Most soil fumigants are currently forbidden or strictly restricted within the European Union (Directive 2009/128/CE) and elsewhere. The use of 1,3-dichloropropene and chloropicrin, or its mixtures, are subjected to the granting of exceptional uses per crop, soil-borne pathogen, and area. Authorizations for the use of metam sodium or dazomet have been cancelled in countries such as France and Spain. Other chemical compounds, such as methyl iodide or sodium azide, among others, have not reached the market, while dimethyl disulfide is still pending registration in the European Union (EU). Therefore, with the current regulatory situation, and except for temporary authorizations, farmers do not currently have chemical alternatives for soil disinfestation, which may compromise the productivity of these intensive strawberry crops and their economic viability if alternatives that are both effective in the control of soil pathogens and profitable are not implemented in the short term [10].

Extensive research has been done on alternative non-chemical methods, such as solarization, biofumigation, steaming and biocontrol agents for controlling soil-fungal diseases in vegetables. However, the efficiencies of all these alternative methods in suppressing SFPs are lower than soil fumigation, and many have not proven consistent enough when used in intensive crop farming [10]. Nevertheless, profitable production can be achieved with lower SFP-suppressing efficacies, providing that the pathogen inocula in soil is reduced to below the tolerance limit for the crop. Long-term field trials comparing the control efficacies of several soil disinfestation methods would provide valuable information for SFP disease management.

The main objective of this research was to compare the efficacies of various soil fumigants and biosolarization in reducing the soil inocula of M. phaseolina and Fusarium spp., suppressing SFP diseases, and increasing strawberry yields.

\section{Materials and Methods}

\subsection{Soil Disinfection Efficacy in Field Trials}

The relative efficacies of various soil disinfestation techniques in reducing SFP populations were compared in field trials at two experimental sites during eleven strawberry cropping cycles.

\subsubsection{Experimental Fields and Strawberry Growing Conditions}

From 2007/08 to 2017/18, nineteen field trials were carried out in the Huelva province (southwestern Spain). The experimental sites were located at Palos de la Frontera $\left(37^{\circ} 14^{\prime} \mathrm{N}\right.$, $6^{\circ} 53^{\prime} \mathrm{W}$ ) (infested with M. phaseolina, Fusarium spp., and M. hapla) and Moguer $\left(37^{\circ} 17^{\prime} \mathrm{N}\right.$, $6^{\circ} 51^{\prime} \mathrm{W}$ ) (infested with M. phaseolina, Fusarium spp., and P. penetrans). Soils were classified 
as loamy-sands with an organic matter content of $0.4-0.8 \%$, pH 6.7-6.9, and electrical conductivity of $0.08-0.11 \mathrm{mS} \mathrm{cm}^{-1}$ at planting in the $2007 / 08$ season.

At both sites, conventional crop management for strawberry production in the region was followed [11]. Briefly, strawberry plants were planted in October in raised beds (50 cm wide $\times 30 \mathrm{~cm}$ high), which were protected by black plastic mulch and had a localized fertigation system. These beds were covered by high tunnels with $0.15 \mathrm{~mm}$ translucent thermic polyethylene plastic, which allowed $60-75 \%$ of the photosynthetic active radiation from November to May to enter. High tunnels, which were $6.6 \mathrm{~m}$ wide and covering six beds, were mounted, and removed every season and built using semicircular steel bars with a $3.3 \mathrm{~m}$ high tunnel apex. Bare-root strawberry plantlets from commercial nurseries were transplanted in the field in October and placed in double rows per raised bed, $25 \mathrm{~cm}$ apart within and between rows. Strawberry cultivars used were "Camarosa" from 2007/08 to 2013/14 and "Fortuna Florida" from 2014/15 to 2017/18 growing seasons. Individual plots $\left(3.3 \times 25 \mathrm{~m}^{2}\right)$, with three raised beds per plot, were delimited on each field site every growing season as experimental units.

\subsubsection{Soil Disinfestation Treatments}

At each location, seven chemical fumigants and biosolarization with chicken manure plus an untreated control were tested. The product dosage, plastic mulch, and means of application are described in Table 1 . Treatments were set in a randomized complete block design with three replicates per treatments $\left(78 \mathrm{~m}^{2}\right.$ and 600 plants per replicate). There were some variations in dosage and way of application in different growing seasons, but every treatment at a specific dosage and way of application was tested at least twice in different cropping cycles and at two locations, with three replicates in each of them $(n=12)$.

Table 1. Soil disinfestation treatments, dosage, way of application, plastic mulch used, and number of replicated plots, applied to fields naturally infested with soil fungal pathogens (SFPs) to determine their efficiencies in reducing their soil inocula.

\begin{tabular}{|c|c|c|c|c|}
\hline Soil Treatment & $\begin{array}{l}\text { Dosage } \\
\text { (kg/ha) }\end{array}$ & Applic. & $\begin{array}{l}\text { Plastic } \\
\text { Mulch }\end{array}$ & Rep. \\
\hline Untreated Control & - & - & PE & 57 \\
\hline 1,3-dichloropropene:chloropicrin (61:33) & 400 & Drip & PE & 21 \\
\hline 1,3-dichloropropene:chloropicrin (61:33) & $300-400$ & Shank & PE & 57 \\
\hline Chloropicrin & $300-400$ & Shank & PE & 57 \\
\hline Allyl isothiocyanate & $200-300$ & Drip & PE & 12 \\
\hline Dazomet & $300-500$ & Broadcast & PE & 39 \\
\hline Dimethyl disulphide & $600-800$ & Shank & $\mathrm{VIF} / \mathrm{DAF}$ & 21 \\
\hline Metam sodium & 153 & Drip & $\mathrm{PE} / \mathrm{VIF}$ & 21 \\
\hline Methyl iodide:chloropicrin (33:67) & 150 & Drip & VIF & 18 \\
\hline Biosolarization chicken manure & $20-25 \mathrm{t} / \mathrm{ha}$ & Broadcast & PE & 45 \\
\hline
\end{tabular}

Dosages are expressed as kg/ha of treated area. Applic.: pre-plant drip-irrigation, shank by two chisels in bed, or broadcast. Plastic mulch: PE: low-density black polyethylene, $50 \mu \mathrm{m}$. VIF: Virtually impermeable film, $30 \mu \mathrm{m}$. DAF: Dimethyl disulfide -approved film. Rep.: Number or repeated plots in which the treatment was applied during the 11 growing seasons, from 2007/08 to 2017/18.

The untreated control was maintained in the same plots from 2009/10 to 2017/18, as well as 1,3 dichloropropene:chloropicrin and chloropicrin shank treatments. The rest of the fumigant treatments were applied on the same plots from their first application. In 2010/11, dazomet was first applied at $500 \mathrm{~kg} / \mathrm{ha}$, but its dosage was reduced to $350 \mathrm{~kg} / \mathrm{ha}$ from the 2013/14 season onwards. In 2013/14 and 2014/15, dimethyl disulfide was applied at $600 \mathrm{~kg} / \mathrm{ha}$ under virtually impermeable film (VIF). Since 2015/16, this product was applied at $800 \mathrm{~kg} / \mathrm{ha}$ under Dimethyl disulfide-approved film (DAF), a gastight film containing ethylene vinyl alcohol developed by Arkema [12].

Prior to any chemical treatment application, the soil in each individual plot was thoroughly tilled and subsequently irrigated with a sprinkler for two consecutive days to ensure the soil was moist at a minimum depth of $20 \mathrm{~cm}$. Soil fumigants were applied by shank-injection or drip-irrigation (Table 1). Fumigants were injected into the soil at 
depths of $20 \mathrm{~cm}$ with two chisels, simultaneously pressing the bed. Chemicals applied by drip-irrigation were delivered through a single drip line, and emitters were placed on bed centers at a depth of $1 \mathrm{~cm}$ every $20 \mathrm{~cm}$, with a flow rate of $5 \mathrm{~L} \cdot \mathrm{m}^{-1} \cdot \mathrm{h}^{-1}$. Dazomet was broadcast applied by a Mix Tiller Dry ${ }^{\circledR}$ (Forigo Roteritalia Srl., Ostiglia, Italy) and raised beds were built and covered with a black plastic mulch just after the agrochemical application. Average soil temperatures during fumigation were between $25-29{ }^{\circ} \mathrm{C}$ at both locations. In all soil fumigation treatments, only the raised bed soil was fumigated, approximately $50 \%$ of the total soil surface of the field. Therefore, the amount of the soil fumigant applied was half the dosage shown in Table 1, though the concentrations of the chemical in soil beds correspond to the dosage shown in Table 1.

Biosolarization is a modified form of solarization that combines organic soil amendments with passive solar heating under a transparent plastic mulch, which creates multiple pest and pathogen inactivation mechanisms in the soil [13]. Biosolarization was applied in mid-July each season. The soil was thoroughly tilled and watered to field capacity before fresh chicken manure from nearby chicken farms was uniformly distributed onto the surface of the soil and then incorporated into the top $20 \mathrm{~cm}$ layer by crosswise ploughing using a rotary cultivator (Rotavator; Howard Iberica S.A., Granollers, Spain). If needed, plots were then drip-irrigated until the soil reached field capacity again. Solarization was carried out under a low-density transparent polyethylene film $(0.03 \mathrm{~mm}$ thick) during July and August for about 6-8 weeks. After that, the polyethylene film was removed, and the soil was then left dry and uncultivated until it was prepared for planting in October.

\subsubsection{Estimation of Soil Borne Pathogen Inocula in Soil}

Composite soil samples were taken from each plot just before applying the soil disinfestation treatments (P0) and after the treatments at planting (Pi) to determine SFPs inocula. Since each soil treatment was carried out in a different sampling time, soil samples were taken also from the untreated control at the same time as each soil treatment to estimate the reductions in SFP inocula due to the soil treatments. On each sampling time, seven soil cores were taken per plot using a vertical soil core sampler $(2 \mathrm{~cm}$ diameter $\times 20 \mathrm{~cm}$ deep), and cores were mixed in a composite soil sample. Two subsamples of $100 \mathrm{~g}$ of mixed soil were used to estimate the soil fungal inocula. Macrophomina phaseolina was identified morphologically according to [14] and its soil inoculum was estimated as number of colony-forming units (CFU) per g of soil. For M. phaseolina isolation, air-dried soil samples were prepared following a modification of the Papavizas and Klag technique $[15,16]$. Soil inocula of Fusarium spp. was estimated as numbers of CFU per $\mathrm{g}$ of soil, serial dilutions were made, and a semi-selective agar medium (V-8) was used [17]. Fusarium spp. were identified morphologically following [17].

Treatment efficacies in reducing SFP inocula were determined using the SchneiderOrelli's correction, Formula (1), based on soil inocula reductions from P0 to Pi (mortality) and corrected by the natural mortality in the untreated plots from the corresponding field trial and growing season [18].

$$
\text { Mortality }=[1-(\mathrm{Pi} / \mathrm{P0})]
$$

Schneider-Orelli's corrected efficacy $=[(\mathrm{mt}-\mathrm{mc}) /(1-\mathrm{mc})] \times 100$

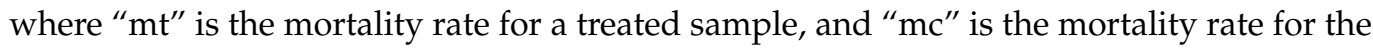
untreated control.

\subsubsection{Estimation of Plant Mortality and Strawberry Yield}

The incidence of soil fungal disease symptoms in each plot were recorded weekly throughout each season. Dead plants from the central bed of each plot were recorded and collected until mid-May for diagnosis [13], and the incidence of mortality was expressed as percentage of dead plants, with respect to the untreated control. 
Fruits were harvested twice a week from approximately early January to mid-May. Data from each harvest were recorded for each plot individually. Only marketable fruits were weighed, and data were expressed as $\mathrm{kg} / \mathrm{ha}$. A minimum of 25 harvests were made each season.

\subsection{Statistical Analyses}

Data are expressed as the mean \pm standard error of the mean and were analyzed with the Statgraphics Centurion XVI ${ }^{\circledR}$ (Statpoint Technologies Inc., Warrenton, VA, USA) statistical software. Data from repeated experiments in time were analyzed by ANOVA to check for differences between experiments; since no significant differences were found, the data were grouped in one single set of data. The Kolmogorov-Smirnov and Brown-Forsythe tests were applied to data to check for normality and homoscedasticity of variances; if significant, data were arcsine-transformed and subjected to the same tests once more. When normality and homoscedasticity of variances could be assumed, data were analyzed by ANOVA. If F values were significant, the means were compared by the Bonferroni test $(p<0.05)$. When the homoscedasticity of variances could not be assumed, Welch's ANOVA was used.

\section{Results}

Fusarium oxysporum and F. solani were the most frequently isolated species from soil samples at both locations. All treatments reduced M. phaseolina and Fusarium spp. soil inocula significantly, compared to the untreated control (Figure 1), without differences in dosages or the mode of application. Soil disinfestations with chloropicrin, allyl isothiocyanate, dazomet, 1,3-dichloropropene:chloropicrin, methyl iodide:chloropicrin, and dimethyl disulfide reduced Fusarium spp. and M. phaseolina soil inocula by more than $90 \%$. Biosolarization with chicken manure was the least efficient method in reducing both SFP inocula, with less than $81 \%$ efficacy. Metam sodium was highly efficient in reducing $M$. phaseolina soil inoculum (100\%), but it was less efficient in reducing Fusarium spp. (88\%).

All treatments reduced strawberry plant mortality compared to mortality in untreated controls from 30\% (metam sodium) to $77 \%$ (allyl isocyanate) (Figure 2). Symptoms of charcoal rot, caused by M. phaseolina, were observed in field since the 2009/10 growing season at the Moguer site and since the 2010/11 growing season at the Palos site, though from the 2011/12 growing season, mortality due to charcoal rot was similar at both sites [19]. Treatments such as 1,3-dichloropropene:choropicrina, allyl isocyanate, dazomet, or dimethyl-disulfide reduced the incidence of charcoal rot below 1\% (data not shown).

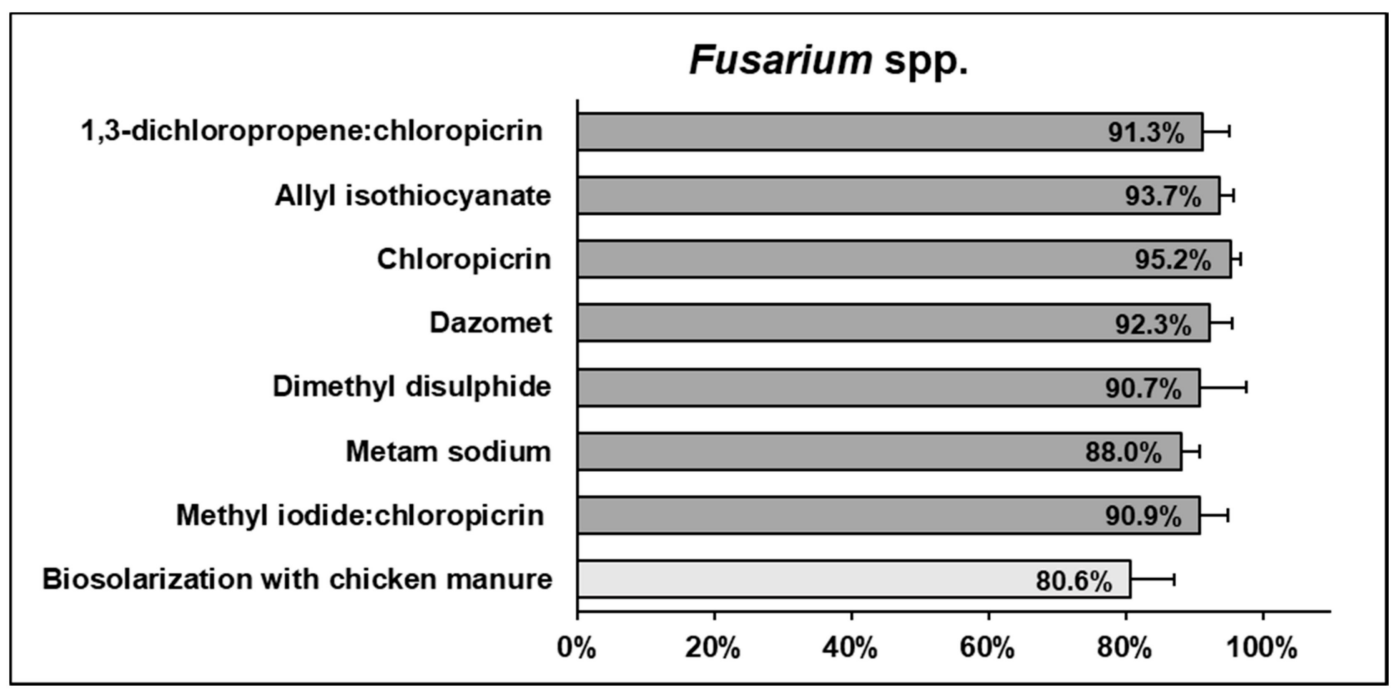

(a)

Figure 1. Cont. 


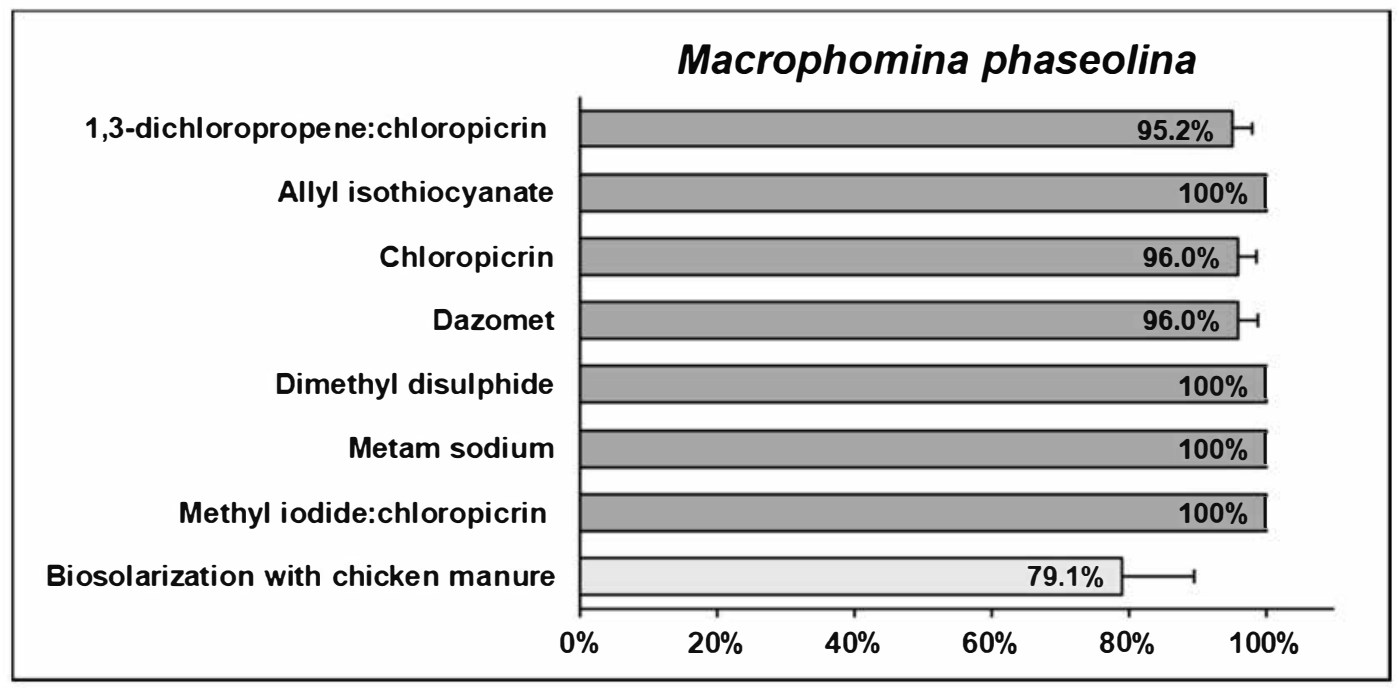

(b)

Figure 1. Average relative efficiencies in reducing SFP soil inocula of several soil disinfestation treatments in strawberry fields: Fusarium spp. (a) and Macrophomina phaseolina (b). Data are the mean of 12 to 57 replicates depending on the treatment and obtained during 11 growing seasons. Error bars represent the standard error of the mean. Bars filled with the same shade of grey do not differ significantly according to the Bonferroni test $(p<0.05)$.

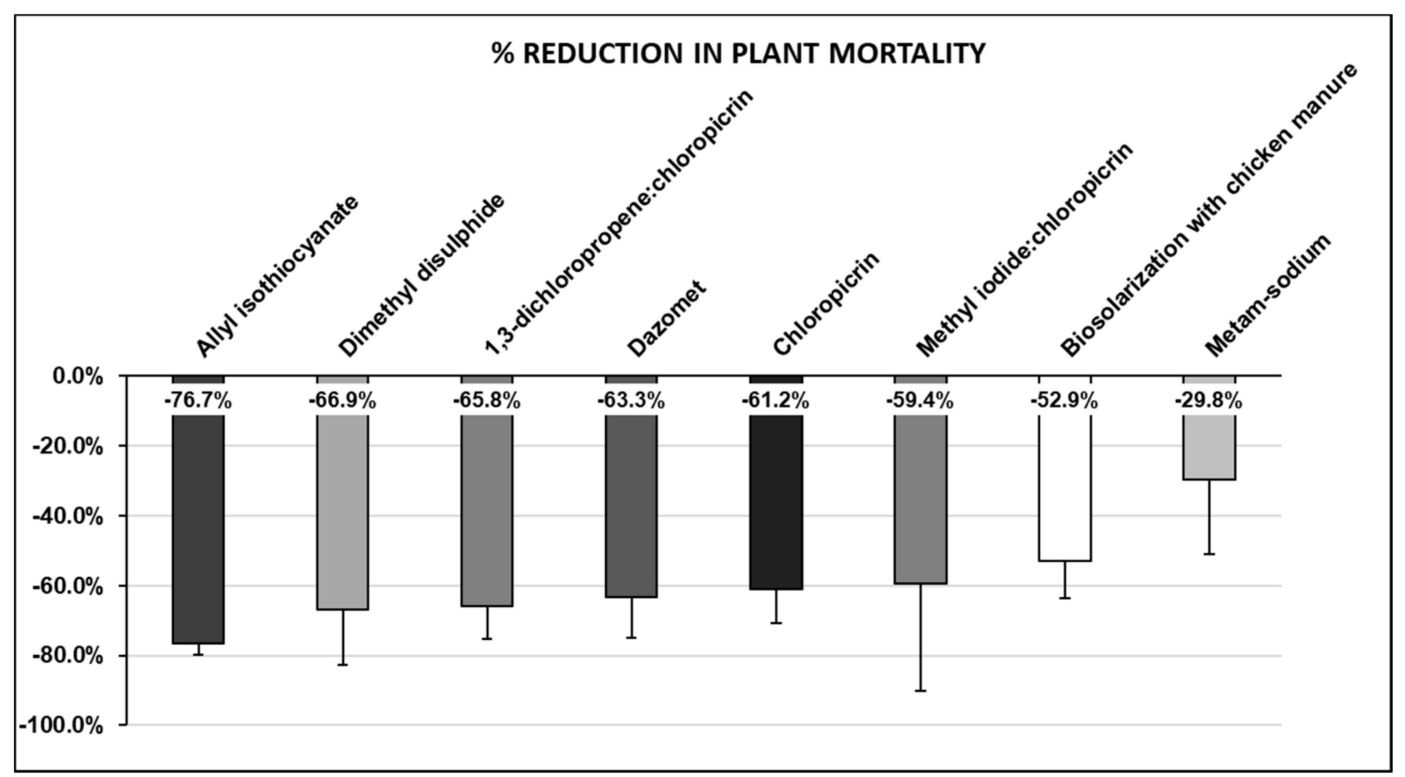

Figure 2. Average relative reductions in plant mortality under different soil disinfestation treatments, compared to untreated controls. Data are the mean of 12 to 57 replicates depending on the treatment and obtained during 11 growing seasons. Error bars represent the standard error of the mean.

All fumigated plots showed an increase in strawberry yields when compared to untreated plots (Table 2). Plots treated with allyl isothiocyanate, 1,3-dichloropropene:chloropicrin, dazomet, and chloropicrin increased the strawberry yield significantly over the untreated controls (Table 2). Furthermore, strawberry yields in the allyl isocyanate-treated plots were significantly higher than those obtained in metam sodium- and methyl iodide:chloropicrintreated plots. 
Table 2. Average strawberry yields per growing season obtained after soil disinfestation treatments in fields naturally infested with several soil-borne pathogens.

\begin{tabular}{lc}
\hline \multicolumn{1}{c}{ Soil Treatment } & Yield (Kg/ha) \\
\hline Untreated Control (UC) & $55,755 \pm 2597 \mathrm{c}$ \\
Allyl isothiocyanate & $81,227 \pm 1567 \mathrm{a}$ \\
1,3-dichloropropene:chloropicrin (61:33) & $72,234 \pm 2806 \mathrm{ab}$ \\
Dazomet & $72,125 \pm 3773 \mathrm{ab}$ \\
Chloropicrin & $71,678 \pm 2928 \mathrm{ab}$ \\
Biosolarization with chicken manure & $68,035 \pm 2865 \mathrm{abc}$ \\
Dimethyl disulphide & $64,587 \pm 2395 \mathrm{abc}$ \\
Metam sodium & $63,304 \pm 3993 \mathrm{bc}$ \\
Methyl iodide:chloropicrin (33:67) & $59,239 \pm 2707 \mathrm{bc}$ \\
\hline
\end{tabular}

Data are expressed as mean \pm standard error of the mean. Data are the mean of 12 to 57 replicates depending on the treatment and obtained during 11 growing seasons. Values in each row followed by the same letter do not differ significantly according to the Bonferroni test $(p<0.05)$.

\section{Discussion}

Soil-borne pathogens have a high prevalence in South Spain strawberry crops; plantparasitic nematodes were found in $90 \%$, Fusarium spp. in $82 \%$, and M. phaseolina in $21 \%$ of the fields during a survey in 2017 in the strawberry-growing area of Huelva [7,8]. The wide distribution of these pathogens pose a risk for the crop. Despite annual soil disinfestations in $83 \%$ of the fields, farm advisors estimated that between $6-10 \%$ of their yield losses were due to SFPs and nematodes [8]. Furthermore, if soils were not disinfested, or less-effective disinfestation techniques were used, perceptions on yield losses would probably rise.

Conventionally, broad-spectrum fumigants have been used to effectively reduce SFP inocula in soil and to increase strawberry yields, but the use of these has fallen drastically in the European Union [9]. As reported by Gao and Wilhoit [20], the most effective treatment for reducing nematode soil densities is still the soil fumigant 1,3dichloropropene:chloropicrin, whose efficacies were from 78-87\% [7], and it provided also high efficacies, over $90 \%$, in reducing M. phaseolina and Fusarium spp. soil inocula. However, higher soil-borne pathogen incidence has been detected at lower dosages of 1,3-dichloropropene:chloropicrin (303 kg/ha) compared to full rates (605 kg/ha) [21]. Therefore, reduced dosages of 1,3-dichloropropene:chloropicrin may be sufficient for adequate nematode control in sandy soils but are not enough for the control of some soil-borne pathogens such as Fusarium spp. Mixtures of 1,3-dichloropropene and chloropicrin work synergistically to control a wide range of plant pathogens and pests, which include fungi, nematodes, insects, mites, rodents, weeds, and some bacteria, and have been recommended as being the best option for controlling mixed infestations by SFPs and nematodes in many intensive crops. However, at present, 1,3-dichloropropene:chloropicrin is not included among substances permitted in the European Union (European Directive 2009/128CE), and it can only be used under temporary authorizations.

Despite not being as effective as 1,3-dichloropropene:chloropicrin, other chemicals such as dimethyl disulfide or dazomet could provide a sufficient level of nematode control when Meloidogyne densities at planting were lower than $100 \mathrm{~J} 2$ per $100 \mathrm{~g}$ of soil [7]. Since these chemicals also showed high efficacies in reducing Fusarium spp. and M. phaseolina soil inocula, they are a plausible alternative to the mixture 1,3-dichloropropene:chloropicrin, when nematode densities at planting are not extremely high. Reductions in plant mortality and yield increases in fields co-infested by nematodes, Fusarium spp., and M. phaseolina supported the effectiveness of these soil fumigants, since plant mortality was reduced by $60 \%$, and strawberry yield increased by more than $28 \%$ over the untreated controls. Dimethyl disulfide has zero ozone depletion potential, and it is reported to have a complex mode of action affecting mitochondrial function and causing inhibition of cytochrome oxidase, so it has been reported as more environmentally friendly than other fumigants [22]. However, its use is not yet approved within the European Union, since it is still under revision. 
Allyl isothiocyanate and chloropicrin were highly efficient in reducing Fusarium spp. or M. phaseolina inocula, but chloropicrin had a low efficiency in reducing nematode populations (28-30\%) [7] and we do not have data on the allyl isothiocyanate effect on nematodes in strawberry crops. However, on other vegetables, allyl isothiocyanate showed a good efficacy against Meloidogyne, Fusarium, Phytophthora, and Pythium species, improving plant vigor and marketable yield $[23,24]$. Allyl isothiocyanate was also effective against $M$. phaseolina, being as effective as 1,3-dichloropropene:chloropicrin in soils where strawberry was grown [25]. Similarly, our results show that allyl isothiocyanate soil treatments reduce pathogenic fungal populations and plant mortality, and increase fruit yields as one of the most effective treatments.

Dimethyl disulfide and isothiocyanates have been identified as volatile compounds produced when soil is amended with brassicas and solarized. Isothiocyanates are also related to the active ingredient in the commercial fumigants metam sodium and dazomet. Isothiocyanates from chemical synthesis or natural origins have been reported repeatedly as suppressants of SFPs and nematodes on strawberry $[23,26]$, and could be a promising alternative to soil chemical fumigants.

Despite that the mixture methyl iodide:chloropicrin was highly effective in reducing nematode populations [7], Fusarium spp., and M. phaseolina soil inocula, reductions in plant mortality and increases in fruit yield were the lowest among all the fumigants tested. Methyl iodide:chloropicrin (33:67) at $225 \mathrm{lbs/acre,} \mathrm{under} \mathrm{virtually} \mathrm{impermeable} \mathrm{films} \mathrm{(VIF),}$ provided a $100 \%$ control of $F$. oxysporum soil population [27] and methyl iodide:chloropicrin (30:70), under polyethylene (PE), reduced the survival of $M$. phaseolina by up to $97 \%$, but did not eradicate it [28]. Furthermore, the high toxicity profile of methyl iodide has prevented its authorization as plant protection product in many countries.

Metam sodium only showed a high efficiency in reducing M. phaseolina soil inocula, but it was less efficient in reducing nematode or Fusarium spp. populations. Metam sodium consistently provided the most effective control of inoculum of $M$. phaseolina (sclerotia, and naturally-infected crowns and stolons), whereas chloropicrin or 1,3dichloropropene:chloropicrin were not consistently as effective as metam sodium on strawberry crops [29]. In our field trials, plots treated with metam sodium showed more plant mortality and less fruit yield than other fumigants, probably due to a lower control of Fusarium spp. populations.

Non-fumigant soil disinfestation in strawberry production, such as steam, biofumigation, solarization, or soil-less cultivation, are not highly effective methods of reducing SBP soil inocula, and are uneconomical if used on their own [10]. However, combining biofumigation with organic manures plus soil solarization has proved to be an efficient way of controlling weeds and soil-borne diseases in strawberries, such as Rhizoctonia spp., Phytophthora cactorum, and M. phaseolina, in Turkey and Spain $[16,19,30]$. In our field trials, soil biosolarization reached efficacies of about $80 \%$ reduction for Fusarium spp. and M. phaseolina soil inocula, and reductions in plant mortality and fruit yield increase over the untreated controls did not differ between chemically fumigated and biosolarized plots. Therefore, biosolarization could be considered a viable alternative to chemical soil fumigation in strawberry crops of Southern Spain. However, under high pressure of SFP, efficacies in reducing SFP under $80 \%$ may not provide enough control to keep plant mortality low and maintain profitable fruit yields. Besides, at dosages of $20,000 \mathrm{~kg} / \mathrm{ha}$, the availability of chicken manure may not be sufficient if the biosolarization technique extends over the 7000 ha dedicated to strawberry cultivation in Huelva. Other sources of organic matter, such as Brassicaceae residues or sugar vinasses, have shown effectiveness in the control of strawberry soil-borne pathogens $[16,31,32]$ and could provide enough organic matter for biosolarization treatments, but they need to be further tested in field trials.

\section{Conclusions}

Soil fungal pathogens are effectively controlled by chemical fumigation of soils in intensive strawberry crops in Spain. In the case of mixed infestations by nematodes 
and fungi, the most efficient treatment in suppressing strawberry soil-borne diseases caused by nematodes, Fusarium spp., and M. phaseolina was soil fumigation with 1,3dichloropropene:chloropicrin, but other alternative chemicals, such as allyl isothiocyanate, dazomet, and dimethyl disulfide, provided high efficacies in reducing the SFP inocula and plant mortality, and increasing fruit yields. Soil biosolarization is proposed as an effective alternative to chemical soil fumigation for strawberry cultivation in Southern Spain when SFP inocula is not remarkably high.

Author Contributions: J.J.M., M.T., B.d.I.S. and L.M. conceived and designed the experiments; J.A.G. and L.M. carried out the field experiments; J.J.M., M.T., B.d.l.S. and L.M. analyzed the data; B.d.I.S. and M.T. wrote the paper. All authors have read and agreed to the published version of the manuscript.

Funding: This work has been financially supported by grants IFAPA, PP.AVA.AVA2016.010, PP.AVA. AVA2019.034, and PP.TRA.TRA2019.004 and FEDER funds from the European Union.

Institutional Review Board Statement: Not applicable.

Informed Consent Statement: Not applicable.

Data Availability Statement: Data sharing not applicable.

Conflicts of Interest: The authors declare no conflict of interest. The founding sponsors had no role in the design of the study; in the collection, analyses, or interpretation of data; in the writing of the manuscript, and in the decision to publish the results.

\section{References}

1. FAO FAOSTAT: Statistical Database. Available online: http://www.fao.org/faostat/en/\#home (accessed on 30 May 2020).

2. MAPAMA. Anuario de Estadística 2018; Ministerio de Agricultura, Pesca y Alimentación: Madrid, Spain, 2019 ; pp. 1-849.

3. Avilés, M.; Castillo, S.; Bascon, J.; Zea-Bonilla, T.; Martín-Sánchez, P.M.; Pérez-Jiménez, R.M. First report of Macrophomina phaseolina causing crown and root rot of strawberry in Spain. Plant Pathol. 2008, 57, 382. [CrossRef]

4. Arroyo, F.T.; Llergo, Y.; Aguado, A.; Romero, F. First report of Fusarium wilt caused by Fusarium oxysporum on strawberry in Spain. Plant Dis. 2009, 93, 323. [CrossRef]

5. Pastrana, A.M.; Capote, N.; De los Santos, B.; Romero, F.; Basallote-Ureba, M.J. First report of Fusarium solani causing crown and root rot on strawberry crops in Southwestern Spain. Plant Dis. 2014, 98, 161. [CrossRef]

6. Borrero, C.; Capote, N.; Gallardo, M.A.; Avilés, M. First report of vascular wilt caused by Fusarium proliferatum on strawberry in Spain. Plant Dis. 2019, 103, 581. [CrossRef]

7. Talavera, M.; Miranda, L.; Gómez-Mora, J.A.; Vela, M.D.; Verdejo-Lucas, S. Nematode management in the strawberry fields of southern Spain. Agronomy 2019, 9, 252. [CrossRef]

8. Talavera, M.; Gómez-Mora, J.A.; de los Santos, B.; Miranda, L.; Vela, M.D.; Fernández-Plaza, M.; Medina-Mínguez, J.J.; Soria, C.; Verdejo-Lucas, S. Problemática fitopatológica del cultivo de la fresa en Huelva. Agricultura 2018, 1022, 6-9.

9. López-Aranda, J.M.; Domínguez, P.; Miranda, L.; de Los Santos, B.; Talavera, M.; Daugovish, O.; Soria, C.; Chamorro, M.; Medina, J.J. Fumigant use for strawberry production in Europe: The current landscape and solutions. Int. J. Fruit Sci. 2016, 8362, 1-15. [CrossRef]

10. Greco, N.; López-Aranda, J.M.; Saporiti, M.; Maccarini, C.; de Tommaso, N.; Myrta, A. Sustainability of European vegetable and strawberry production in relation to fumigation practices in the EU. Acta Hortic. 2020, 1270, 203-210. [CrossRef]

11. Romero-Gámez, M.; Suárez-Rey, E.M. Environmental footprint of cultivating strawberry in Spain. Int. J. Life Cycle Assess. 2020, 25, 719-732. [CrossRef]

12. Fouillet, T.; Rebizak, R.; Descamps, S.; Ciesla, Y.; Guery, B. Development of a new gastight film containing EVOH. Acta Hortic. 2014, 1044, 301-305. [CrossRef]

13. Domínguez, P.; Miranda, L.; Soria, C.; de Los Santos, B.; Chamorro, M.; Romero, F.; Daugovish, O.; López-Aranda, J.M.; Medina, J.J. Soil biosolarization for sustainable strawberry production. Agron. Sustain. Dev. 2014, 34, 821-829. [CrossRef]

14. Holliday, P.; Punithalingam, E. Macrophomina phaseolina. In C.M.I. Descriptions of Pathogenic Fungi and Bacteria; Commonwealth Mycological Institute: Kew, UK, 1970; p. 275.

15. Papavizas, G.C.; Klag, N.G. Isolation and quantitative determination of Macrophomina phaseolina from soil. Phytopathology 1975, 65, 182-187. [CrossRef]

16. Chamorro, M.; Miranda, L.; Domínguez, P.; Medina, J.J.; Soria, C.; Romero, F.; López Aranda, J.M.; de los Santos, B. Evaluation of biosolarization for the control of charcoal rot disease (Macrophomina phaseolina) in strawberry. Crop Prot. 2015, 67, 279-286. [CrossRef]

17. Leslie, J.F.; Summerell, B.A. The Fusarium Laboratory Manual; Blackwell Publishing: Ames, IA, USA, 2006 ; pp. 1-388.

18. Schneider-Orelli, O. Entomologisches Praktikum; Verlag Sauerländer: Aarau, Germany, 1947; pp. 1-237. 
19. Chamorro, M.; Domínguez, P.; Medina, J.J.; Miranda, L.; Soria, C.; Romero, F.; López Aranda, J.M.; Daugovish, O.; Mertely, J.; de los Santos, B. Assessment of chemical and biosolarization treatments for the control of Macrophomina phaseolina in strawberries. Sci. Hortic. 2015, 192, 361-368. [CrossRef]

20. Gao, S.; Wilhoit, L. Fumigant use and transition from methyl bromide to alternatives in California. In Proceedings of the 2011 Annual International Research Conference on Methyl Bromide Alternatives and Emissions Reductions, San Diego, CA, USA, 31 October-2 November 2011.

21. Cabrera, J.A.; Hanson, B.D.; Abit, M.J.M.; Gerik, J.S.; Gao, S.; Qin, R.; Wang, D. Efficacy of 1,3-dichloropropene plus chloropicrin reduced rates under two different tarps against nematodes, pathogens and weeds. In Proceedings of the 2011 Annual International Research Conference on Methyl Bromide Alternatives and Emissions Reductions, San Diego, CA, USA, October 31 October-2 November 2011.

22. Dugravot, S.; Grolleau, F.; Macherel, D.; Rochetaing, A.; Hue, B.; Stankiewicz, M.; Huignard, J.; Lapied, B. Dimethyl disulfide exerts insecticidal neurotoxicity through mitochondrial dysfunction and activation of insect KATP channels. J. Neurophysiol. 2003, 90, 259-270. [CrossRef] [PubMed]

23. Ntalli, N.; Caboni, P. A review of isothiocyanates biofumigation activity on plant parasitic nematodes. Phytochem. Rev. 2017, 16, 827-834. [CrossRef]

24. Ren, Z.; Li, Y.; Fang, W.; Yan, D.; Huang, B.; Zhu, J.; Wang, X.; Wang, X.; Wang, Q.; Guo, M.; et al. Evaluation of allyl isothiocyanate as a soil fumigant against soil-borne diseases in commercial tomato (Lycopersicon esculentum Mill.) production in China. Pest Manag. Sci. 2018, 74, 2146-2155. [CrossRef]

25. Baggio, J.S.; Chamorro, M.; Cordova, L.G.; Noling, J.W.; Vallad, G.E.; Peres, N.A. Effect of formulations of Allyl Isothiocyanate on survival of Macrophomina phaseolina from strawberry. Plant Dis. 2018, 102, 2212-2219. [CrossRef] [PubMed]

26. Hoffmann, M.; Ajwa, H.A.; Westerdahl, B.B.; Koike, S.T.; Stanghellini, M.; Wilen, C.; Fennimore, S.A. Multitactic preplant soil fumigation with Allyl Isothiocyanate in cut flowers and strawberry. Horttechnology 2020, 30, 251-258. [CrossRef]

27. Othman, M.; Hunzie, J.; Koike, S.; Gordon, T.; Ajwa, H. Paladin (DMDS), Midas, and Pic-Clor 60 for strawberry production in California. In Proceedings of the 2011 Annual International Research Conference on Methyl Bromide Alternatives and Emissions Reductions, San Diego, CA, USA, 31 October-2 November 2011.

28. Hutton, D.G.; Gomez, A.O.; Mattner, S.W. Macrophomina phaseolina and its association with strawberry crown rot in Australia. Int. J. Fruit Sci. 2013, 13, 149-155. [CrossRef]

29. Zveibil, A.; Mor, N.; Gnayem, N.; Freeman, S. Survival, host-pathogen interaction, and management of Macrophomina phaseolina on strawberry in Israel. Plant Dis. 2012, 96, 265-272. [CrossRef]

30. Benlioğlu, S.; Boz, Ö.; Yildiz, A.; Kaşkavalci, G.; Benlioğlu, K. Alternative soil solarization treatments for the control of soil-borne diseases and weeds of strawberry in the western Anatolia of Turkey. J. Phytopathol. 2005, 153, 423-430. [CrossRef]

31. Lodha, S.; Sharma, S.K.; Aggarwal, R.K. Solarization and natural heating of irrigated soil amended with cruciferous residues for improved control of Macrophomina phaseolina. Plant Pathol. 1997, 46, 186-190. [CrossRef]

32. Ntalli, N.G.; Caboni, P. Botanical nematicides: A review. J. Agric. Food Chem. 2012, 60, 9929-9940. [CrossRef] [PubMed] 